\title{
Belgian Communism in the Light of Its Vanishing (1976-1994)
}

\author{
Pascal Delwit \\ Université libre de Bruxelles, Brussels, Belgium \\ Email: pdelwit@ulb.ac.be
}

How to cite this paper: Delwit, P. (2018). Belgian Communism in the Light of Its Vanishing (1976-1994). Open Journal of Political Science, 8, 316-337.

https://doi.org/10.4236/ojps.2018.83023

Received: July 4, 2018

Accepted: July 27, 2018

Published: July 30, 2018

Copyright $\odot 2018$ by author and Scientific Research Publishing Inc. This work is licensed under the Creative Commons Attribution International License (CC BY 4.0).

http://creativecommons.org/licenses/by/4.0/

\begin{abstract}
In the 1987 national elections, the Communist Party of Belgium (PCB-KPB) lost all parliamentary representation for the first time since 1925. This failure reflects the accelerated collapse of Belgian Communism in just a decade. The events of 1989 and 1991 in Central and Eastern Europe and in the USSR will then confirm the de facto disappearance of the PCB-KPB. The article goes back to the roots of the decline of a medium-size Communist Party, but showed political and social relevance from 1925 to 1985 . The decline is due to the industrial and socio-demographic dramatic changes. The paper also tackles the political choices made in the seventies and eighties to understand it. In particular, it embraces the internal paralysis of the party faced with the challenges posed to all the European Communist Parties at this time, and its inability to deal with them.
\end{abstract}

\section{Keywords}

Belgian Communism, Party Politics, Belgian Politics, Radical Left Parties, Communist Party, Communist Party of Belgium

\section{Introduction}

As of 1976, the year of the municipal elections in Belgium, in the early nineties, the Communist Party of Belgium (Particommuniste de Belgique-Kommunistische Partij van België, PCB-KPB) experienced a considerable fall in its aura, to the point of losing, as it was, any electoral, political, cultural and trade union influence after 1989. During this period, its falling-off had a timeline that was not particularly original for most European Communist Parties (Delwit, 2016).

In a nutshell, the life of the Belgian Communists can be divided into three phases. The first involved both electoral stability and the introduction into the 
party of some of the militant forces that took part in the 1968 student and trade union movements. The second, at the turning point of the seventies and eighties, testified to the onset of a complex period, made up of significant electoral and political setbacks. The third, which began with the 1985 legislative elections, marked the beginning of the end of the PCB-KPB in Belgian political and trade union life. In 1985, for the first time since 1925, the Communist Party lost all parliamentary representation. In the 1981 legislative elections, it had kept only two MPs-Daniel Fedrigo and Jacques Nagels, later replaced by Didier Bajura, and one senator-Jules Vercaigne (see Table 1).

This setback revealed the acceleration of a decline, which de facto led to the disappearance of Belgian Communism, 68 years after its creation. The events in 1989 - the fall of the Berlin Wall-and in 1991-the collapse of the Soviet Union-did not therefore upset but rather confirmed or exacerbated earlier developments.

As we have noted, this trajectory is not, strictly speaking, specific, but it affected a Communist Party that displayed a number of distinctive features in the communist world. In Belgium, the Communist Party was never a movement in the format of the French, Italian, Cypriot or Finnish, or then again German and Czechoslovak Communists in the inter-war years, but it was one of the few Communist Parties to have been able to show relevance (Sartori, 1976) since the 1920 s and to have kept it up throughout its history. This relevance was expressed in electoral terms but could also be observed on the Belgian social scene, dominated as it was by the classic struggle between employers' and trade union organisations but also by a struggle for influence between trade unions of socialist leanings and trade unions with a Christian democratic orientation (Spitaels, 1974).

Moreover, the $\mathrm{PCB}-\mathrm{KPB}$ also showed a degree of originality in its relations

Table 1. Evolution of the number of seats at the Chamber captured by the PCB-KPB (1921-1991).

\begin{tabular}{llll}
\hline 1921 & $0 / 182$ & 1961 & $5 / 212$ \\
\hline 1925 & $2 / 187$ & 1965 & $6 / 212$ \\
1929 & $1 / 187$ & 1968 & $5 / 212$ \\
1932 & $3 / 187$ & 1971 & $4 / 212$ \\
1936 & $9 / 202$ & 1974 & $2 / 212$ \\
1939 & $9 / 202$ & 1977 & $2 / 212$ \\
1946 & $23 / 202$ & 1978 & $4 / 212$ \\
1949 & $12 / 212$ & 1981 & $2 / 212$ \\
1950 & $7 / 212$ & 1985 & $0 / 212$ \\
1954 & $4 / 212$ & 1987 & $0 / 212$ \\
1958 & $2 / 212$ & 1991 & $0 / 212$ \\
\hline
\end{tabular}

Source: Ministry of Interior. 
with the USSR and the People's Democracies, displaying a Euro communist positioning in the 1970s (Pons 2010), cautiously, though. Initially, moreover, the PCB-KPB refuted the term ${ }^{1}$. Then, under pressure from several sectors of the party, the group did-cautiously-endorse it.

In this contribution, we analyze the sources of an accelerated decline by looking at the classical socio-political indicators in the three phases mentioned earlier. We also examine how the PCB-KPB changed statutorily in the light of a Belgian context, which enshrined the evolution from a unitary nation State to a decentralized and, ultimately, a Federal State (1993). We will then consider the explanations for the failure of the Communist Party to adapt to societal transformations. Finally, we look at the evolution of the Communist Party's standpoints in international matters, its reactions and its silence faced to 1989 events, the August 1991 coup and the collapse of the USSR.

\section{The Belgian Communist Dynamic Until 1989}

1) The electoral point of view: from reaffirmation to vanishing

Four national elections took place in Belgium in the 1970s. All showed a long-known reality for the Belgian communists. PCB-KPB was evanescent in the Dutch-speaking part of the country. It posted a convincing score only in the 1946 elections and, to a lesser extent already, in 1949 (See Table 2).

On the other hand, it could boast a degree of consistency in Brussels and Wallonia. In Wallonia, the Communist Party was relatively stable. It reached $5.9 \%, 5.8 \%, 5.3 \%$ and 5.8\% respectively in the 1971, 1974, 1977 and 1978 legislative elections. In the district that comprises the capital Brussels, it achieved 2.8\%, 4\%, 2.7\% and 3\%. In Flanders, as we have said, the PCB-KPB had a much more limited scope and at these four elections it scored only $1.59 \%, 1.59 \%, 1.23 \%$ and $1.90 \%$.

In the early eighties it suffered a sudden slump. In the 1981 legislative elections, the Communist Party had to endure a significant decline: it kept only two members of Parliament and one senator. Moreover, through the "apparentement' technical measure (Pilet, 2007), its two most important representatives, Louis Van Geyt of Brussels, the party president, and Marcel Levaux of Liège, were dismissed in favor of less well-known personalities, namely Jacques Nagels of Brabantwallon and Daniel Fedrigo of Huy.

The Communist Party showed a penetration which remained significant only in the areas of old industrial settlements: Borinage, the industrial belt of Liège, Charleroi and its periphery. Brussels could be added, even if it has begun a deep tertiarisation process. In Flanders and the rest of the Walloon territory, the

${ }^{1}$ In his book, President Louis Van Geyt attributes this initial reluctance towards the term to an allergy on his and Vice-President Claude Renard's parts: "We have committed blunders. For example, we have hesitated for too long to openly claim Eurocommunism persuasion. We were probably practicing a more Eurocommunist policy than in other CPs. But we had an allergy to that term, as it was not clear to us. On this point, I particularly lay the blame on the Van Geyt-Renard tandem" (Van Geyt, 2015: p. 340). 
Table 2. Evolution of the National elections results of the Communist Party of Belgium in Flanders and Wallonia from 1946 to 2010 (In percentage).

\begin{tabular}{|c|c|c|}
\hline & Wallonia & Flanders \\
\hline 1946 & 21.47 & 5.21 \\
\hline 1949 & 12.58 & 3.47 \\
\hline 1950 & 7.80 & 2.44 \\
\hline 1954 & 6.67 & 1.49 \\
\hline 1958 & 4.47 & 0.04 \\
\hline 1961 & 6.35 & 0.63 \\
\hline 1965 & 9.53 & 0.11 \\
\hline 1968 & 6.90 & 1.38 \\
\hline 1971 & 5.82 & 0.65 \\
\hline 1974 & 5.52 & 1.60 \\
\hline 1977 & 5.39 & 1.24 \\
\hline 1978 & 5.82 & 1.80 \\
\hline 1981 & 4.24 & 1.29 \\
\hline 1985 & 2.50 & 0.48 \\
\hline 1987 & 1.60 & 0.40 \\
\hline 1991 & 0.30 & \\
\hline 1995 & 0.33 & \\
\hline 1999 & 0.46 & \\
\hline 2003 & 0.46 & \\
\hline 2007 & 0.83 & \\
\hline 2010 & 0.83 & \\
\hline
\end{tabular}

Source: Ministry of Interior.

Communist Party already acted as an insignificant though not unknown actor (See Figure 1).

The stark warning of the legislative elections was confirmed and amplified in the 1982 municipal elections (see below). Therefore, in the 1984 European elections, but especially in the 1985 national elections, the Communist Party was nearly wiped out. Not only did it lose all parliamentary representation, but it no longer seemed able to win it back.

The result of the 1987 national election confirmed and amplified the failure of 1985. In the space of ten years, the PCB-КРB lost more than two thirds of its voters homogeneously in Belgium. After 1987, the Communist Party almost disappeared from the electoral scene, with no hope of a real recovery. At the $3^{\text {rd }}$ French-speaking Congress in February 1989, the Communists admitted it ${ }^{2}$.

The Communist Party presented a list only in a few districts during the 1991

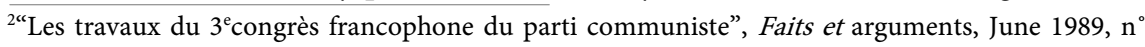
90, p. 14. 


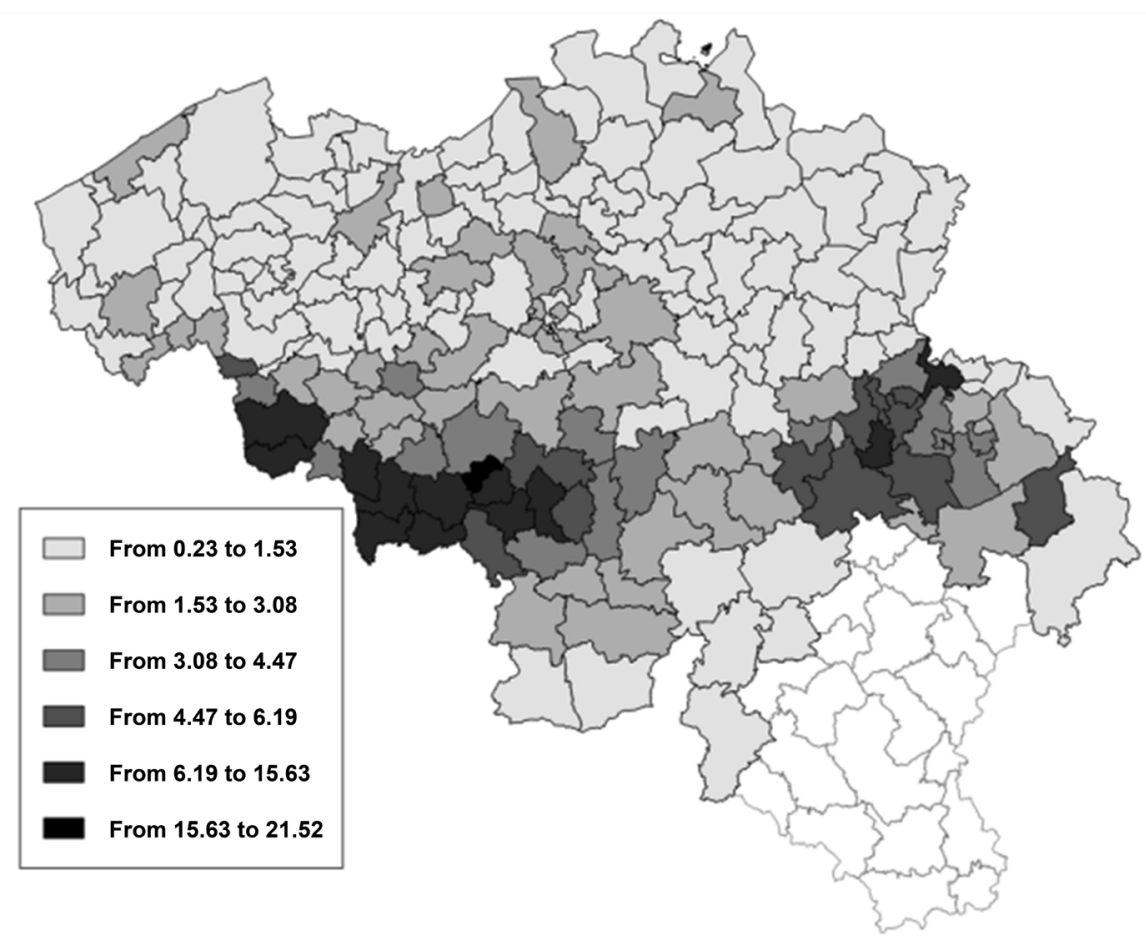

Figure 1. Electoral Geography of the CPB-KPB at the 1981National Elections.

and 1995 elections, with anecdotal results. Over this decade of electoral collapse, we can gauge the massive impact of the loss of influence in the long industrialised territories-steel, metallurgy, mining and textiles-in the Liège and Hennuyer basins.

In Hainaut, the Communist Party lost three quarters of its voters in nine years. This fall proved even heavier at local level. An examination of performance in the 1976, 1982 and 1988 municipal elections bears witness to this.

Generally speaking, local elections tend to be a complex appointment for a medium and small party. Drawing up lists at local level and collecting signatures in order to be able to submit them, all are very difficult tasks, often unattainable in municipalities of limited size from a socio-demographic point of view. Moreover, winning one or more seats is complex since, in the distribution of seats, it is the Imperiali divider that is used rather than the D'hondt divider, applied in national elections (Delwit, 2018: p. 188). Therefore, the Communist Party is only capable of partially "covering" Belgian territory. Its presence is only guaranteed in large municipalities or areas where it has significant presence. In the light of this element, its presence in Flanders is extremely limited as well as in the boroughs of the Namur and Luxembourg provinces in Wallonia. Above all, its presence is dwindling. In 1976, the Communist Party presented a list in 108 of the 589 Belgian municipalities (see Figure 2). Six years later, the Communists were only present in 76 localities (see Figure 3). And in 1988, it fell to 66 (See Figure 4).

At the same time, as already mentioned, its electoral performance declined 


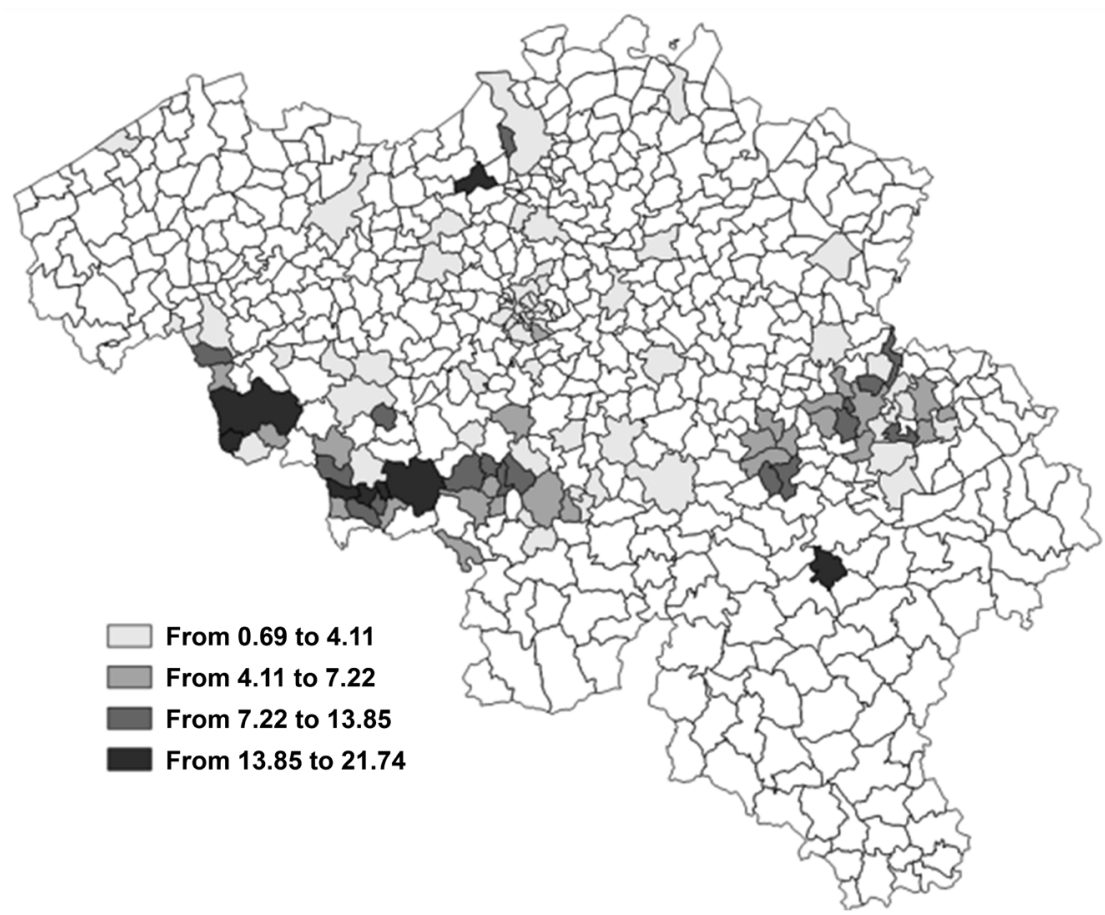

Figure 2. Electoral Geography of the PCB-KPB at the 1976 Local Elections.

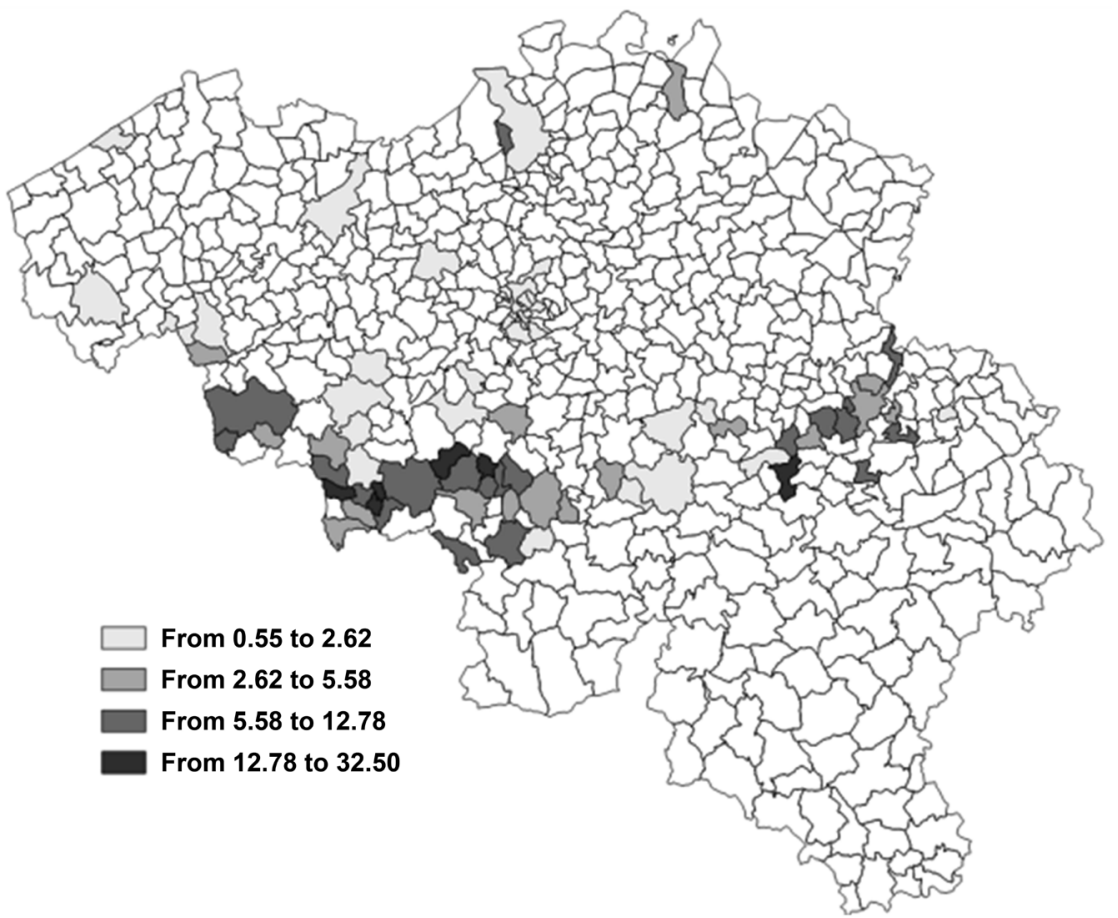

Figure 3. Electoral Geography of the PCB-KPB at 1982 Local Elections.

significantly, as shown in Figure 3 and Figure 4. In 1976, Communist lists exceeded $5 \%$ of the votes in forty-five communes and $10 \%$ in twenty. In 1988, the $5 \%$ mark was exceeded in only 28 cases and the $10 \%$ figure in only 11 municipalities. 


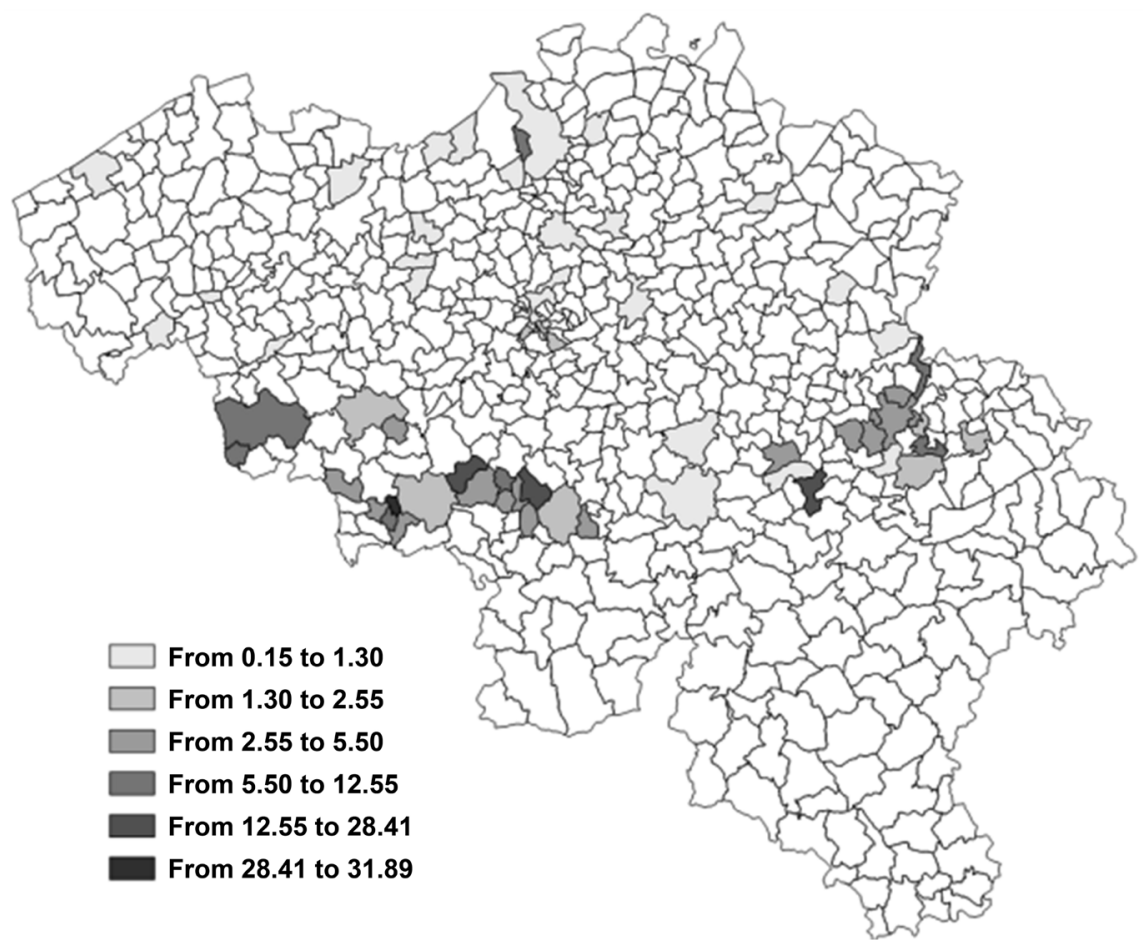

Figure 4. Electoral Geography of the PCB-KPB at 1988 Local Elections.

In 1988 , the fall was drastic. The $5 \%$ threshold was surpassed in only fifteen localities and the $10 \%$ mark in four (See Figure 4).

Logically, this tumble seriously impacted the number of local councillors who won. It stood at seventy-nine in 1976, fell to fifty-five in 1982 and twenty-three in 1988 (see Table 3). In twelve years, therefore, the party lost most of the experience accumulated in local management and the contribution of reference political figures for the electoral segments they targeted.

2) The evolution of the Communist Party's membership since 1975

The evolution in the number of party members was in line with the electoral performance curve. The Communist Party reached its membership pinnacle at the Liberation. In 1945, the PCB-KPB had 88,000 members. The beginning of the Cold War, the normalisation of political life in Belgium (Conway, 2015) and the PCB-KPB's sectarianism quickly caused this total to fall. It was stuck in the ten and fifteen thousand range until the early seventies. From this moment on, the Communist Party recorded a slow but continuous decline in an overall context, marked by a general decrease of Party membership in Europe (Delwit, 2011; van Haute \& Gauja, 2015).

In 1972, the PCB-KPB's numbers fell below ten thousand; in 1978, below nine thousand; and in 1981 below eight thousand. In three years, the party suffered a marked decline from 7583 members (1981) to 5528 (1984). The 1985 electoral failure, confirmed in 1987, reduced the Communist Party to a very modest size relatively to this indicator. Already in 1987, the PCB-KPB boasted only 3372 members (see Table 4). 
Table 3. Number of Communist Local councillors after the 1976, 1982 and 1988 local elections ${ }^{3}$.

\begin{tabular}{|c|c|c|c|c|c|c|c|}
\hline & 1976 & 1982 & 1988 & & 1976 & 1982 & 1988 \\
\hline Anderlecht & 1 & & 0 & Amay & & 1 & \\
\hline Brussels & 1 & & 0 & Marchin & 1 & & \\
\hline Bernissart & 1 & 1 & & Modave & 1 & 2 & 2 \\
\hline Chapelle-Lez-Herlaimont & & 1 & & Comblain au Pont & & 1 & \\
\hline Charleroi & 1 & 1 & & Flémalle & 1 & 1 & \\
\hline Châtelet & & 1 & & Herstal & 2 & 1 & \\
\hline Courcelles & 4 & 3 & 4 & Liège & 2 & 1 & \\
\hline Manage & 2 & 3 & 2 & Oupeye & & & \\
\hline Boussu & 4 & 2 & & Saint-Nicolas & 2 & 1 & \\
\hline Colfontaine & 3 & 3 & 1 & Seraing & 4 & 3 & 1 \\
\hline Dour & 2 & & & Soumagne & & & \\
\hline Frameries & 1 & 1 & & Sprimont & & & \\
\hline Hensies & 3 & 4 & & Trooz & 1 & 1 & 1 \\
\hline Mons & 6 & 2 & & Visé & 2 & 2 & \\
\hline Quaregnon & 6 & 5 & 5 & Hotton & 2 & & \\
\hline Mouscron & 3 & & & Zwijndrecht & 1 & 1 & 1 \\
\hline La Louvière & 2 & 2 & 1 & Tamise & 6 & & \\
\hline Le Roeulx & 5 & 6 & 4 & Total & 79 & 55 & 23 \\
\hline Morlanwelz & 1 & 2 & & & & & \\
\hline Rumes & 2 & 1 & & & & & \\
\hline Tournai & 6 & 2 & 1 & & & & \\
\hline
\end{tabular}

Source: Ministry of Interior and Le Drapeau rouge.

Table4. Evolution of the Communist Party membership from 1944 to 1989.

\begin{tabular}{llllll}
\hline 1944 & 11,306 & 1960 & 11,589 & 1976 & 9523 \\
1945 & 87,892 & 1961 & 13,985 & 1977 & 9269 \\
1946 & 76,194 & 1962 & 14,465 & 1978 & 8792 \\
1947 & 57,295 & 1963 & 14,064 & 1979 & 8790 \\
1948 & 44,683 & 1964 & 14,157 & 1980 & 8135 \\
1949 & 38,361 & 1965 & 14,320 & 1981 & 7583 \\
1950 & 24,360 & 1966 & 13,421 & 1982 & 6846 \\
1951 & 22,215 & 1967 & 12,927 & 1983 & 5957 \\
1952 & 19,276 & 1968 & 12,159 & 1984 & 5528 \\
1953 & 17,000 & 1969 & 11,634 & 1985 & 5446 \\
1954 & 16,239 & 1970 & 10,553 & 1986 & 5044 \\
1955 & 14,265 & 1971 & 10,012 & 1987 & 3372 \\
1956 & 13,664 & 1972 & 9953 & 1988 & 3134 \\
1957 & 11,794 & 1973 & 9570 & 1989 & 3000 \\
1958 & 11,328 & 1974 & 9450 & & \\
1959 & 11,345 & 1975 & 9600 & & \\
\hline
\end{tabular}

Source: Data collected by the author and Centre for Communist Archives in Belgium.

${ }^{3}$ To this total should be added the occasional participation of a communist councillor, elected on a socialist list or based on municipal interests. 
On the eve of the collapse of the Berlin Wall, the Communist Party retained around 2500 members in Wallonia and 500 in Brussels. For the most part, these were long-standing registered members, for whom departure was not an option. But its potential driving forces had deserted the party and no renewal dynamics had been set in motion. In 1987, a survey conducted by the party on its affiliates' profiles in Wallonia revealed that only a little over $10 \%$ of them were at least 30 years of age. On the other hand, $43 \%$ were 56 years old or older at the time, and $15 \%$ had reached their seventies (see Table 5).

The collapse of communist regimes and affiliates' age structure made it possible to grasp that, by the yardstick of this indicator, the party had de facto disappeared. According to the calculations of delegates present at the Saint-Vaast congress held in March 1995, only some 1080 members remained in the mid-1990s. Only a few federations in Hainaut or Liège still were large enough (see Table 6).

At the celebration the party organized in October 1996 for its seventy-fifth anniversary, it claimed a little less than 2000 members. Actually, at that date, membership was in the order of six hundred, spread mainly over a few towns in Hainaut and the province of Liège. In Brussels, and in the provinces of Namur and Luxembourg, the party existed only on paper.

\section{Reasons for an Accelerated Decline}

Whether we observe it on the basis of the electoral indicator or by the yardstick of membership trends, the Communist Party posted a major decline in its influence at the beginning of the 1980s. How can we grapple with this sudden breakdown that continued throughout the 1980s? Let us first remember this was not unique among European Communist parties. In truth, most of them recorded the same type of dynamics.

Table 5. Age distribution of the Communist Party members in Wallonia (In percentage).

\begin{tabular}{cc}
\hline Up to 20 years & 1.1 \\
\hline $21-25$ years & 3.3 \\
26 - 30 years & 6.0 \\
$31-35$ years & 8.9 \\
36 - 40 years & 12.0 \\
$41-45$ years & 8.7 \\
$46-50$ years & 7.6 \\
$51-55$ years & 8.7 \\
$56-60$ years & 11.1 \\
$61-65$ years & 10.9 \\
$65-70$ years & 6.9 \\
70 years and more & 14.8 \\
\hline
\end{tabular}

Source: Centre for Communist Archives in Belgium. 
Table 6. Federations' distribution of PCB party members in 1995.

\begin{tabular}{ccc}
\hline & Borinage & 105 \\
Hainaut & Centre & 105 \\
& Charleroi & 150 \\
Brabant wallon & Tournai & 90 \\
Brussels & Brabant wallon & 45 \\
& Brussels & 75 \\
Liège & Huy & 105 \\
& Liège & 325 \\
Namur & Ourthe Amblève & 30 \\
Luxembourg & Namur & 30 \\
\hline
\end{tabular}

Source: Data collected by the author and Centre for Communist Archives in Belgium.

1) The emergence of another socio-professional world

With regard more specifically to the Communist Party of Belgium, let us pinpoint two major drivers of this changeover. The first is socio-demographic. In its history, the PCB-KPB had mainly established itself in the working-class Walloon basins and in the Brussels white- and blue-collar environment. Its presence and influence was affected by two important developments affecting these basins. Indeed, they went through major economic restructuring. Until the early 1950s, Belgium's economic driver was mainly located in the south of the country. But shortly after WWII, the situation changed. Some key sectors were affected in the 1950s by European competition from a modernised tool and by changes in the energy sector. Coal mines in Wallonia were the hardest-hit.

In the 1960s and 1970s, mines dwindled and with them a community in which the Communist Party had conquered its strongest social and political positions. At the end of the 1970s, only ... 2657 miners remained in Wallonia (Bruwier, 1988: p. 202) (Table 7).

The same applies to the textile sector. Simultaneously, a partial intra-Belgian south to north transfer took place. Part of the Belgian steel industry settled by the sea: the SIDMAR pole-Maritime steel industry-was born. The issue of industrial conversion in Wallonia became part of the debate and was one of the fundamental facts of the strike of the century (December 1960-January 1961) that affected Belgium, but especially Wallonia.

The second sequence refers to the turning-point of the seventies. The new international division of labour caused production relocations that had a greater impact on the industrial base in Wallonia. Employment in the metallurgy and steel industries was badly affected. This was precisely where the communists were best integrated. Within a few years, the Communist Party lost many of its reference points in its social and political action. This loss of reference was all the more marked as a change in the institutional constraint also affected it. The 
Table 7. Evolution of the total of mineworkers in Belgium (1948-1984).

\begin{tabular}{ccccccc}
\hline & Belgium & Campine & Liège & Charleroi & Centre & Mons-Borinage \\
\hline 1948 & 177,177 & 44,060 & 33,315 & 44,507 & 24,055 & 31,180 \\
1961 & 88,541 & 33,830 & 16,117 & 23,138 & 6202 & 9254 \\
1964 & 84,991 & 34,551 & 16,076 & 22,353 & 4511 & 7400 \\
1969 & 40,961 & 21,468 & 5717 & 9460 & 1464 & 2852 \\
1974 & 27,881 & 18,834 & 2746 & 5187 & 0 & 1114 \\
1979 & 21,220 & 18,563 & 451 & 2206 & 0 & 0 \\
1984 & 17,673 & 17,673 & 0 & 0 & 0 & 0 \\
\hline
\end{tabular}

Source: Bruwier, 1988.

beginning of the seventies was indeed the time for an important merger of municipalities in Belgium. This grouping drowned and isolated a number of communist personalities who had played a role in some municipalities even if, as José Gotovitch (1994: p. 308) pointed out, "municipal communism" had never, strictly speaking, existed in Belgium. The examples of René Noël and Victor Piérard, mayors of Cuesmes (with absolute majority from 1970 to 1976), Elie Hoyas, mayor of Thieu, René Mathy, mayor of Vyle-Tharoul, Léon Philippe, mayor of Warzée, or Marcel Levaux, mayor of Cheratte, are emblematic.

While the service economy and the tertiary sector were progressing noticeably, the Communist Party remained largely attached to the industrial world, which was in full decline. Members' socio-professional origins during the 1980s showed this considerable gap between the social composition of the party's affiliates and the changing reality of the Belgian society's workforce.

Of course, the results we have calculated require a degree of caution. First, because categorization does not take members' ages into account. We therefore do not know whether the members interviewed were still active at the time of the survey. In addition, the totals were obtained from the information provided by members on their membership stub, where nine choices were offered. This sometimes led to discrepancies between the subjectively experienced status and reality, especially regarding members who had worked in more than one occupation. Half of the Walloon PCB-KPB members belonged to it (49.6\%). If, to the category "private sector workers", we add that of "public sector workers", which then represented about $10 \%$, we obtained a total of $60 \%$ of workers. Such over-representation of the working class highlights the under-representation in the other categories, especially among employees (See Table 8).

2) The PCB-KPB and the useful voting

The difficulties encountered by the Belgian Communists at the turning point of the 1970s and 1980s occurred in Belgium's specific domestic context, marked by political and social polarisation. At the beginning of the decade, the impact of the economic crisis on public finances put social partners and political actors under pressure. As in many countries, employers and the political right pressed 
Table 8. Socio-professional status of PCB-KPB party members in Wallonia (In percentage).

\begin{tabular}{cc}
\hline Private-sector Working Class & 49.6 \\
\hline Public-sector Working Class & 9.6 \\
Private-sector Employees & 11.7 \\
Public-Sector Employees & 10.0 \\
Teaching Professions & 6.7 \\
Para-medical Professions & 2.3 \\
Culture industry personnel & 2.0 \\
Students & 1.8 \\
Free Professions & 6.3 \\
\hline
\end{tabular}

Source: Centre for Communist Archives in Belgium.

for a reduction in the level of social benefits and a shift towards a supply-side fiscal policy. In 1981, the Belgian Socialists were sent into opposition against a neoliberal government, associating Christian Democrats and liberals (Delwit 2012).

It is in this context that the political and social organisations with socialist leanings tightened their links to break this Right-wing coalition government. On the eve of the 1985 legislative elections, the Socialist Party and the Walloon interregional FGTB signed an agreement defining a minimum programme to be implemented in a government with socialist participation (Arcq, 1987: p. 16-17). Although formally independent, the Socialist Party and the FGTB thus joined forces in the 1985 National elections. This agreement and the conservative attitude of the PS and the FGTB placed the communist trade union delegates in a difficult situation. Moreover, during the election campaign, the PCB-KPB was confronted with the rationale of useful voting within the left-wing electorate: it was, above all, a matter of breaking the Right-wing coalition government.

3) Choosing not to choose

The fall in electoral results and the collapse of membership both contributed to the crisis of the Communist Party and acted as an indicator of it. As we have observed, there are objective reasons outside the organization that enable us to understand the difficulties encountered by the CPB-KPB. However, these indicators alone cannot explain the decline of the Communist Party. Political choices have also played an essential role.

The most significant feature of the Communist Party's political practice was, without doubt, the search for compromises between supporters of very different lines and perspectives. Schematically, two paths clashed in the late seventies and the early eighties. The first, in line with the course of the Italian Communist Party, was part of the brief dynamic of Eurocommunism. The ambition was to break away from the clichés of anticlerical working classes and outdated revolutionary rhetoric. On the international front, the proponents of this path called for an autonomous positioning towards the Soviet Union, the CPSU and the 
People's Democracies. The strongholds of this sensitivity were to be found in Brussels, in the Mons-Borinage federation, particularly in Mons, around the figure of René Noël (Chauvier, 1973: p. 37; Maerten, 2005), and in the communist pockets in Flanders.

Faced with this vision, a sensitivity, close to the course of the French Communist Party, stongly advocated affirming the historical role of the working class and of the Soviet Union. It was to be found mainly in Liège, the party's biggest federation by the standards of membership (see Table 10), the Outhe-Amblève federation, and, to a lesser extent, the Charleroi federation. In 1976, tensions in the party were harshly expressed at the April congress held in Ghent. The contribution of the Liège federation was to insist so much and more on the importance of fighting against all forms of anti-communism and anti-Sovietism and for supporting socialist countries. In its conclusion, this was harped upon several times ${ }^{4}$.

The Federal Secretary, Albert Juchmès, sent a very long contribution in which he was strongly opposed to the alliance strategy, embodied in the Union of Progressives (UDP), notably with left-wing Catholic organisations. In his opinion, the Communist Party must refocus on four foundations: a) its core of action is the working class; b) it has a revolutionary vocation; c) it is a pre-war party and d) it imposes itself to argue and wrestle against anti-communism and anti-Sovietism. "Any concession in this area, especially in the present circumstances, can only help imperialism and reactionary forces", he said ${ }^{5}$.

Such exacerbation and tension between the two points of view led-against the wishes of the Party President (Estersohn, 1978: p. 22) to the non-election of personalities from Liège to the Central Committee: Marcel Levaux, Marcel Baiwir and Jules Pirlot. As for the candidatures of Albert Juchmès, Jean-Marie Simon and André Dans, they did not get through either (See Table 9).

Table 9. Results of candidates coming from Liège at the Central Commitee (April 1976)

\begin{tabular}{cc}
\hline Baiwir, Marcel & 60 \\
\hline Juchmès, Albert & 34 \\
Levaux, Marcel & 53 \\
Pirlot, Jules & 24 \\
Simon, Jean-Marie & 27 \\
Dans, André & 58 \\
Number of voters & 186 \\
\hline
\end{tabular}

Source: Centre for Communist Archives in Belgium.

${ }^{4}$ Federation of Liège, Contribution au congrès $d u$ parti communiste, 1976. Centre for Communist Archives in Belgium (CARCOB).

${ }^{5}$ Albert Juchmès, Contribution au congrès du parti communiste, 1976 (43 pages). Archives of the Centre for Communist Archives in Belgium (CARCOB).

${ }^{6}$ Congrès du parti communiste de Belgique, Gand, Avril 1976. Archives of the Center for Communist Archives in Belgium (CARCOB). 
Table 10. Distribution of Communist Party members by federation (1971-1989).

\begin{tabular}{|c|c|c|c|c|c|c|c|c|c|c|c|c|c|c|c|c|c|c|c|c|}
\hline Provinces & Federations & 1971 & 1972 & 1973 & 1974 & 1975 & 1976 & 1977 & 1978 & 1979 & 1980 & 1981 & 1982 & 1983 & 1984 & 1985 & 1986 & 1987 & 1988 & 1989 \\
\hline Bruxelles & Brussels & 970 & 984 & 955 & 938 & 952 & 1008 & 975 & 930 & 899 & 765 & 750 & 672 & 617 & 632 & 605 & 571 & 387 & 481 & 388 \\
\hline Brabant wallon & Brabant wallon & 307 & 284 & 277 & 273 & 266 & 296 & 301 & 251 & 226 & 207 & 209 & 201 & 164 & 152 & 158 & 146 & 145 & 146 & 143 \\
\hline \multirow{5}{*}{ Hainaut } & Borinage & 1039 & 1099 & 957 & 810 & 880 & 735 & 787 & 790 & 890 & 865 & 729 & 711 & 534 & 496 & 542 & 471 & 415 & 347 & 287 \\
\hline & Centre & 336 & 335 & 300 & 330 & 336 & 315 & 306 & 363 & 347 & 352 & 383 & 469 & 402 & 306 & 309 & 298 & 268 & 235 & 189 \\
\hline & Charleroi & 1035 & 1081 & 1011 & 978 & 1008 & 1006 & 926 & 925 & 888 & 824 & 771 & 692 & 605 & 527 & 531 & 475 & 441 & 383 & 342 \\
\hline & Thudinie & 294 & 241 & 217 & 187 & 200 & 253 & 254 & 202 & 180 & 204 & 193 & 146 & 152 & 156 & 154 & 127 & 104 & 104 & 82 \\
\hline & $\begin{array}{c}\text { Tournai } \\
\text {-Ath-Mouscron }\end{array}$ & 958 & 912 & 865 & 854 & 870 & 862 & 695 & 680 & 648 & 557 & 572 & 549 & 513 & 441 & 361 & 359 & 318 & 279 & 189 \\
\hline \multirow[t]{2}{*}{ Namur } & Namur & 147 & 117 & 99 & 112 & 130 & 132 & 142 & 131 & 132 & 183 & 195 & 147 & 119 & 79 & 94 & 97 & 87 & 64 & 30 \\
\hline & Liège & 1349 & 1271 & 1303 & 1383 & 1482 & 1585 & 1520 & 1368 & 1269 & 1172 & 1050 & 1007 & 1007 & 947 & 929 & 889 & 869 & 774 & 727 \\
\hline \multirow{3}{*}{ Liège } & Ourthe-Amblève & 133 & 142 & 128 & 139 & 142 & 95 & 127 & 118 & 109 & 111 & 87 & 71 & 50 & 80 & 86 & 72 & 62 & 63 & 65 \\
\hline & Huy-Waremme & 509 & 467 & 385 & 411 & 389 & 448 & 422 & 378 & 482 & 433 & 346 & 282 & 166 & 244 & 300 & 254 & 230 & 219 & 181 \\
\hline & Verviers & 280 & 222 & 234 & 214 & 240 & 218 & 178 & 134 & 151 & 107 & 104 & 77 & 20 & 53 & 57 & 25 & 40 & 32 & 38 \\
\hline Luxembourg & Luxemburg & 62 & 61 & 45 & 0 & 22 & 27 & 31 & 31 & 43 & 24 & 30 & 11 & 0 & 0 & 0 & 5 & 6 & 7 & 1 \\
\hline $\begin{array}{l}\text { Brabant } \\
\text { flamand }\end{array}$ & Flemish Brabant & 190 & 105 & 111 & 117 & 129 & 148 & 141 & 115 & 81 & 74 & 76 & 53 & 61 & 61 & 61 & 24 & & & \\
\hline \multirow{3}{*}{ Anvers } & Antwerp & & 789 & 741 & 719 & 658 & 634 & 654 & 629 & 766 & 670 & 512 & 461 & 415 & & 329 & 309 & & & \\
\hline & Mechelen & & 89 & 92 & 85 & 84 & 78 & 96 & 91 & 92 & 100 & 75 & 64 & 59 & & & 2 & & & \\
\hline & Oostende & & & 77 & 83 & 91 & 75 & 74 & 81 & 84 & 79 & 82 & 52 & 64 & 65 & 65 & 56 & & & \\
\hline \multirow{2}{*}{$\begin{array}{c}\text { Flandre } \\
\text { occidentale }\end{array}$} & Brugge & & & 36 & 26 & 37 & 43 & 62 & 62 & 72 & 69 & 78 & 63 & 63 & 60 & 59 & 59 & & & \\
\hline & $\begin{array}{l}\text { Zuid West } \\
\text { Vlaanderen }\end{array}$ & 277 & 273 & 269 & 254 & 208 & 211 & 218 & 199 & 192 & 173 & 160 & 150 & 143 & 117 & 104 & 105 & & & \\
\hline Limbourg & Limburg & 83 & 86 & 86 & 68 & 73 & 76 & 73 & 70 & 72 & 72 & 73 & 53 & 50 & 50 & 50 & 48 & & & \\
\hline \multirow{2}{*}{$\begin{array}{l}\text { Flandre } \\
\text { orientale }\end{array}$} & Denderstreek & 640 & 678 & 669 & 642 & 595 & 550 & 539 & 534 & 523 & 487 & 434 & 394 & 349 & 337 & 331 & 309 & & & \\
\hline & Ghent & 425 & 576 & 622 & 710 & 677 & 603 & 616 & 596 & 586 & 547 & 501 & 355 & 286 & 256 & 241 & 267 & & & \\
\hline
\end{tabular}

Source: Data collected by the author and Centre for Communist Archives in Belgium.

The Communist Party was thus paralysed by internal divisions, personal bickering and the refusal-more precisely, unwillingness-to go down a clear path. More than any other, President Louis Van Geyt embodied this imperative of a middle path between increasingly distant orientations.

In addition to the impact on the organisation as a whole, this quest for a permanent balance focused the organisation on its internal facet, abandoning its external work and political presence. "There have been other mistakes. For a whole period, I spent too much time commuting with Liege in order to fight Juchmès's positions, the leader of the local federation", said Louis Van Geyt (2015: p. 340) in a 2015 compilation of interviews.

It also prevented the emergence of new leaders who were more sensitive to the new middle classes' demands. Even after the elimination of the party from parliamentary life in 1985 and the upheavals in the USSR in the same year, the Bel- 
gian Communists could not escape this logic.

The Brussels federation and the Communist Youth tried even more to inflect the party's positions towards more distance regarding socialist countries and towards revitalising the party's political line. But they obtained only minor concessions.

\section{Don't Give Up the Heaven}

Quite logically, in the same period, there was a persistent gap between innovative resolutions on international issues and a practice that remained very traditional. Within the framework of relations with the CPSU and the communist movement, the Belgian Communists often distanced themselves from Soviet policy during the great "deals" that shook the communist world: intervention of Warsaw Pact troops in Czechoslovakia (1968), trials against intellectuals in the USSR, occupation of Afghanistan by Soviet troops (1979), coup in Poland (1981). But the forms that these condemnations took are often subtle compromises, reflecting above all the internal balances of the party.

In August 1968, the Communist Party of Belgium sent an open letter to the Communist Parties whose countries took part in the intervention. He stated that he "could not approve of the military intervention (...)" and stressed that "in the present case (they) had given the impression of acting as if it had become impossible to hope for the political changes that would lead to the dismantling of the military blocs and disarmament ${ }^{7}(. .$.$) ". But as soon as the Moscow agreement$ was signed, the MP for Liège, Marcel Levaux, renewed with the Central Committee of the Czechoslovak Communist Party the "solidarity-of the Belgian Communists-for the normalization of the situation and in particular for the withdrawal of the troops, for the consolidation and the development of the Socialist Democracy and the defeats of the reactionary forces". The word "normalization" was obviously most unfortunate in view of the connotation it later took, but its use was not a mere coincidence. Levaux, one of the pro-Soviet party supporters, considered it necessary to mention the "reactionary forces", fifty years after the events in Prague, observers are still looking for the presence among the main actors of the Czechoslovak drama. Thereafter, the president of the party, Marc Drumaux went to Prague to warm up relations between Belgian and Czechoslovak Communists, as well as his future successor and the person in charge of international relations, Augustin Duchâteau.

Following the Soviet intervention in Afghanistan, the Belgian Communists became more cautious. The CPB did not officially react until 7 January 1980, more than ten days after the troops had invaded. It is necessary to read the entire communiqué to arrive at reprobation, wrapped in attacks against the United States?.

\footnotetext{
"Lettre ouverte du parti communiste de Belgique aux partis communistes de l'URSS, de Bulgarie, de Hongrie, de Pologne et de RDA", Le Drapeau rouge, 23 August 1968.

${ }^{8}$ Marcel Levaux, "D’un mal peut-il sortir un bien?", Le Drapeau rouge, 30 August 1968.

"“Communiqué du bureau politique", Le Drapeau rouge, 8 January 1980.
} 
The formula used was so lukewarm that it triggered an internal polemic. The PCB-KPB then became more critical of Soviet policy in Afghanistan, while refusing to support any resistance movement. The disapproval was clearer for the coup in Poland:

"The use of military power in Poland on Sunday and the draconian measures it has taken are incompatible with socialism in a developed country. The Political Bureau therefore disapproved of them"10.

The notion of the "two sides" also gave rise to some internal discussions, but the Communist Party's condemnation was unambiguous. Through these examples and despite the present nuances, the Communist Party's attitude had always been to condemn repression in the East. Nevertheless, "regrets", "disapprovals" or "condemnations" do not, in most cases, go beyond the framework of a specific position. The key concept that used to emerge was the notion of critical solidarity. Depending on the interlocutors, the first or second term of this proposal became more or less important. On the other hand, discussions or compromises at the level of the governing bodies were not very inclined towards the party's base, broad sectors of which remained viscerally attached to the USSR. The infrequent analysis of the USSR before Mikhail Gorbachev's accession to the post of Secretary General of the CPSU wanted the country, in spite of its denounced shortcomings, always to be an indispensable counterweight to American imperialism. Despite its efforts to assert its autonomy, the PCB-KPB remained framed by the situation in the east and largely financed by the Soviet Union. In any case, his positions were characterized by extreme caution, more like diplomatic declarations of chancellery than resolutions of a party, supposedly revolutionary. In retrospect, remarks of Louis Van Geyt (2015: p. 35) illustrate this configuration:

"These countries formed a counterweight to imperialism. And we hoped they could still reform themselves, sufficiently and in good time (...). But we were doing diplomacy. We didn't say, “'YYou're a bunch of imposters, we're breaking up with you"'“.

The state of paralysis but, above all, of decomposition in which the Communist Party already found itself in the mid-1980s largely accounted for the weakness, if not even the absence of reaction of the Belgian party to the Glasnost and Perestroika earthquakes. Mihail Gorbachev's accession to the presidency of the USSR little changed the course of events for the Communist Party in Belgium. There was clear support for the new Secretary General and for the "justified" criticism of past mistakes. Yet Soviet foreign policy was so reversed that even the analyses of parties "critical" of Brezhnev's policy sounded timid, if not complacent, in retrospect, with regard to the new CPSU's positions. Paradoxically, the main changes were once again driven from... Moscow... The PCB-KPB management systematically welcomed the new Soviet initiatives and took them on board... But paradoxically, an extremely classic rhetoric redeployed itself by 10“Pologne: nette désapprobation du parti communiste de Belgique", Le Drapeau rouge, 18 December 1981. 
extrapolating differently from the past. "However, even if this has not always been true (we underline), is it not obvious that today, thanks to a new dynamic approach to problems, the USSR's external policy and the non-aligned countries'action very often converged in a fruitful sense for peace and for cooperation between peoples", stated for example the president of the party at the beginning of 1987 (Van Geyt, 1987: p. 34).

In the fatal year for the communist world, 1989, the main feature that characterized the communist party in the face of events was ... silence. The party continued to function "normally". This silence can be captured in several ways. First, the party had become a shadow of what it used to be. Moreover, the surprise was so great that it left the vast majority of Communists speechless. For some, it was not only a world collapsing but a life. Finally, the intellectuals who were part-members, often at the forefront of the "reformists", had deserted him; at the time when the communist system was collapsing, when a number of communist directions were handing over, there was no one in the party to embody a new line, a new credible leadership. The Communist Party continued its life in a routine, indifferent manner and in November 1989 sent an observer to the fourteenth Congress of Romanian Communists. His report was clearly without concessions ${ }^{11}$.

But did it really take a delegate to the PCR congress to make such a diagnosis, and even when Louis Van Geyt refused to answer several invitations from Nicolae Ceaucescu? Following the fall of the Berlin Wall, the Communist Party held a Conference in March 1990, a Congress in November 1990 and a Congress in St Vaast in March 1995. In these circumstances, the Communist Party did not address head-on the developments in the Soviet Union and the disappearance of People's Democracies. At the convention, the resolution on this collapse was soothing:

"The critical and collective analysis of the history of real socialism and of our positions in relation to it must continue in party organizations ${ }^{12 ”}$.

However, these meetings were not without impact. In March, two resolution texts were submitted to the delegates. But, as it should have been, after two days of extremely hard work and discussions, only one document was put to the vote. The Communist Party recognized that "the CPs, in their traditional forms, (had) lived, and (that) the classically defined functioning inspired by "democratic centralism", today had to redefine itself from a more open scheme of "self-managing pluralism", but no concrete implication of purpose and analysis was advanced. It was no different, besides, regarding electoral turn-out ${ }^{13}$.

The conference admitted the right of some federations to continue their original experience of red/green Forum. This process was born from the will of the

\footnotetext{
${ }^{11}$ Hubert Cambier, "Souveraine ... la Roumanie choisit l'isolement", Le Drapeau rouge, 28 November 1989.

${ }_{12}^{12} 4{ }^{e}$ congrès du parti communiste, Montignies-sur-Sambre, 3/4 November 1990 », Faits et arguments, December 1990, n 95, p. 7

${ }^{13}$ Ibid., p. 2
} 
Brussels activists, still members of the PCB-KPB, to initiate a dialogue and, eventually, an electoral alliance with the environmental movement. Faithful to what then was its logic "neither to the left nor to the right", Ecolo-the French speaking Green Party-refused any collaboration with an outdated party. The red/green Forum initiative aborted after a few months.

Another original attempt was the transformation of the communist daily newspaper Le Drapeau rouge-the Red Flag. On 1 January 1991, the Communist paper changed its militant name to a less marked one, Freedoms-Libertés. The new project was intended to be a pluralistic expression of the left. However, the editorial team remained unchanged and funding was almost exclusively provided by the Communist Party. The experiment failed within months of its launch. In view of the developments in the Netherlands, Italy and the United Kingdom, the party had a brief debate on the name of the party. Logically enough, given the absence of debate on the substance, the communist label was maintained.

In a way, the PCB-KPB's relationship with the USSR ended with the attempted coup in August 1991 and the collapse of the Soviet system. The Communist Party reacted twice to the events of 19 August 1991 in Moscow. The first occurred before the outcome. On 20 August, the Bureau of the now Union of Belgian Communists mentions its anxiety and implicitly condemned, but not explicitly, the coup, which would lead to a deadlock ${ }^{14}$.

Two elements must be pointed out. The first one is the lack of any explicit condemnation of the coup attempt, which is not described in such terms. Probably more strikingly is the fact there is no support for the restoration of Gorbachev in power.

On 2 September, the Belgian Communists delivered another communiqué and, this time, explicitly mentioned the coup. The communiqué came in the form of a Farewell to the CPSU and to the homeland of socialism:

"Through the implication of essential sectors of its apparatus in the failed coup, the CPSU has ultimately demonstrated its inability to participate in the profound democratic changes which are desired by the Soviet's Union people"15.

It took the disappearance of the USSR, the collapse of the CPSU for, internally, a last step pinpointed the implications and consequences of a dynamic at work for a long time ${ }^{16}$.

\section{The Evolution of the PCB-KPB's Internal Structure}

When looking at the fate of the Communist Party in Belgium, the difficult adaptation to the sociological and institutional realities of the country is also symbolic of the difficulty of choosing and concentrating one's energy on the internal

\footnotetext{
${ }^{14}$ Avancées démocratiques, September 1991, n ${ }^{\circ}$ 8, p. 15.

${ }^{15}$ Avancées démocratiques, September 1991, n 98, p. 16.

${ }^{16}$ PC-DOC, November 1991, p. 2-3.
} 
dimensions of the organization. In Belgium, the first major State reform took place in 1970, the second in 1980 and the third in 1988.To date, the vast majority of political actors have adapted to this change in the Belgian institutional configuration; sometimes even preceded it. However, the Communist Party of Belgium moved only reluctantly despite its early promotion of federalism ${ }^{17}$. And in this movement, the last phase-that of the "regionalization" of the party - intervened only in ... 1989. It effectively created a French-speaking party and a Dutch-speaking party. It betrays a desperate attempt by management to take advantage of the many changes and challenges around the world to aim for a "complete" political and structural overhaul.

When, in the 1980s, the Communist Party reviewed its organization in the light of institutional changes in Belgium, it was the last party represented in Parliament to retain a national structure. The Christian Democrats split in 1968, the Liberals in 1972 and the Socialists in 1978. As for the new parties, they were immediately distinct according to the linguistic role. As an example, the French-speaking Greens-Ecolo were born in 1980 while their Dutch-speaking alter ego-Agalev was born in 1982.

The PCB-KPB first changed its organization and functioning at a special congress in December 1982. The approach was not implemented with a cheerful heart. Forced and bitter, the Party President conceded in June of this year some necessity to move forward ${ }^{18}$.

Power which had formally been attributed to national organs-the Party Congress, Central Committee and Political Bureau-were from this point onwards divided between the national level and the regional or community level, in accordance with Article 15 of the New Statutes:

"The federal organs of the $\mathrm{CPB}$ are competent in all matters in regional and community interest so far as their elaboration and execution are concerned. $\mathrm{Na}$ tional organs of the $\mathrm{CPB}$ are competent in regard to:

1) All problems concerning the Belgian road to socialism (...);

2) All matters which would remain of national interest in a federal State, and more particularly, international policy;

3) Any question still to evolve which by virtue of the law remains within the remit of the central government and national parliament (...);

4) Management of party finances and patrimony as well as the policy of cadres"19.

These transformations lead to the creation of regional/federal structures-the

${ }^{17}$ After the first State refom, the Communist Party will clearly favour federalism in Belgium organized around three regions and two Communities: "(...) The communists are fighting for a real federalisation of the country, which implies the granting to the two Communities and to the three Regions truesresponsibilities exercised democratically on demarcated territories, with defined powers and competences". Particommuniste de Belgique, Que veulent les communistes? 30 questions pour un débat loyal, 1972, p. 23.

18 "Rapport et réponse de L. Van Geyt au $24^{e}$ congrès du PCB", Faits et arguments, june 1982, n65, p. 18.

${ }^{19}$ Statuts du Parti Communiste de Belgique, Texte adopté par la deuxième session du $24^{e}$ congrès du PCB, Brussels, the $18^{\text {th }}$ of December 1982, p. 15. 
French-speaking Council and Bureau on the one hand, the Flemish Council and Bureau on the other-in parallel with the maintenance of national structures. These reforms, which were aimed at catching up with the party, considerably increased the party's functioning, even though it faced major challenges and was in militant decline. This very often led it to paralysis and to a situation of "permanent congress" and of "continuous meetings"; each of the bodies having to meet in turn to renew its political line and direction.

Above all, this late attempt was quickly overtaken by the country's institutional evolution and by the endless community conflicts within the Communist Party itself. In a context of existential questionings and after many discussions, the March 1989 convention assumed the de facto creation of two parties. On the Flemish side, given its low weight in terms of numbers and electoral results, the Flemish wing of the PCB-KPB looked more like a small group than a party. The French-speaking part of the Communist Party now included two regional parties, Walloon and Brussels. Three governing bodies were set up: the French-speaking Convention, the French-speaking Council and the French-speaking Board. The federation structure was maintained, but at this time, some are much more virtual than material.

\section{Conclusion}

Since its creation, the PCB-KPB has mainly focused its action on industrial centres in the Hainaut, Liège and Brussels areas. The same was true, but in a more focused way, in the Antwerp metropolis and the industrial periphery of Ghent. In Brussels and Wallonia, these trade union and political strongholds of the workers' movement suffered a slow decline which accelerated during the 1960s and 1970s. The Communist Party had founded its trade union, political and electoral influence in and through these sectors. Faced with this accelerated break-up, it found itself without answers, all the more so because, in the meantime, the Soviet Union was losing much of its aura and attractiveness. The social base that constituted and participated in the influence, even in the very existence, of the Communist Party was pulled out from under its feet.

The party's inability to reach and attract a number of segments of the growing social categories is glaringly obvious except, very partially, in Brussels. These external factors largely explain the blurring of the Belgian Communist Party from the Belgian political and social landscape in the 1980s.

Nevertheless, they do not by themselves account for the communist collapse in Belgium. The practice of a permanent balancing act in domestic and international politics, the refusal to make intelligible political choices outside the organization, all focused its attention on the practice of domestic and international diplomacy, which was unattractive and uninteresting to the outside world.

The PCB-KPB was sitting on the fence between a more working-class and pro-Soviet branch, and a more intellectual and Eurocommunist current. At a time when it was hardly more than the shadow of what it used to be, the Com- 
munist Party maintained this attitude in the face of upheavals in Central and Eastern Europe and the Soviet Union. It refused to engage in a genuine debate on the essence of what was happening in People's Democracies and to reflect on its past positions.

It is unlikely that another practice would not have enabled it to survive as it stands, since it is true that, whatever the lines taken by the European Communist parties, all-with the specific exception of the AKEL in Cyprus (Charalambous, 2007) - have been politically and socially affected in this decade. On the other hand, it is imaginable to think that it could have had a completely different impact on the reformulation or refoundation of a pole to the left of Social Democracy, on the socio-economic field and on new themes, such as the struggle for environmental protection, in line with the establishment of Groen Links in the Netherlands (Voerman, 2010; Voerman \& Lucardie, 2016), the People's Socialist Party in Denmark, the Left Socialist Party in Norway or the Left Party in Sweden (Christensen, 1996; 2010; Olsen, 2010), or even the Red-Green List in Denmark. Hypothetically, this might have enabled it to keep on playing a leading role in the social, political and intellectual debate to the left of the Belgian political spectrum (Gotovitch, 2008: p. 32).

\section{Conflicts of Interest}

The authors declare no conflicts of interest regarding the publication of this paper.

\section{References}

Arcq, E. (1987). Les structures internes de la FGTB. Courrier hebdomadaire du CRISP, 1155, 1-32. https://doi.org/10.3917/cris.1155.0001

Bruwier, M. (1988). Que sont devenus les mineurs des charbonnages belges? Une première approche: Problématique et méthodologie. Revue belge d'histoire contemporaine, $X I X(1-2), 173-203$.

Charalambous, G. (2007). The Stronger Communists in Europe: Accounting for AKEL's Electoral Success. Journal of Communist Studies and Transition Politics, 23, 425-456. https://doi.org/10.1080/13523270701507071

Chauvier, J.-M. (1973). Gauchisme et nouvelle gauche en Belgique. I. Courrier hebdomadaire du CRISP, 600-601, 1-42.

Christensen, D. A. (1996). The Left-Wing Opposition in Denmark, Norway and Sweden: Cases of Euro-Phobia? West European Politics, 19, 525-546. https://doi.org/10.1080/01402389608425149

Christensen, D. A. (2010). The Danish Socialist People's Party: Still Waiting after All These Years. In J. Jonathan Olsen and M. Koß (Eds.), Dan Hough, Left Parties in National Governments. London: Palgrave, 121-137. https://doi.org/10.1057/9780230282704_8

Conway, M. (2015). Les chagrins de la Belgique. Libération et reconstruction politique 1944-1947. Brussels: Editions du CRISP.

Delwit, P. (2011). Still in Decline? Party Membership in Europe. In E. van Haute (Ed.), Party Membership in Europe: Exploration into the Anthills of Party Politics. Brussels: 
Editions de l'Université de Bruxelles, 25-42.

Delwit, P. (2012). La vie politique en Belgique. Brussels: Editions de l'Université de Bruxelles.

Delwit, P. (2016). Les gauches radicals en Europe. XIX'e-XXI siècles. Brussels: Editions de l'Université de Bruxelles.

Delwit, P. (2018). Introduction à la science politique. Brussels: Editions de l’Université de Bruxelles.

Estersohn, W. (1978). Le parti communiste de Belgique devant la dissidence et l'eurocommunisme (1968-1978). Courrier hebdomadaire du CRISP, 807-808, 1-42.

Gotovitch, J. (1994). Le parti communiste et les elections communales 1926-1952. In Les elections communales et leur impact sur la politique belge (1890-1970). Brussels: Crédit communal de Belgique, 293-308.

Gotovitch, J. (2008). Le parti communiste de Belgique: Un avatar de la social-démocratie. Revista de Historia Actual, 6, 27-33.

Maerten, F. (2005). René Noël et l'Union démocratique et progressiste, 1971-1982. À la recherche d'un autre communism dans un Borinage en crises. Revue belge d'histoire contemporaine, 15, 435-459.

Olsen, J. (2010). The Norwegian Socialist Left Party: Office-Seekers in the Service of Policy. In J. Jonathan Olsen, M. Koß, \& D. Hough (Eds.), Left Parties in National Governments (pp. 1-15). London: Palgrave. https://doi.org/10.1057/9780230282704_2

Pilet, J.-B. (2007). Changer Pour gagner? Les réformes des lois électorales en Belgique. Brussels: Editions de l'Université de Bruxelles.

Pons, S. (2010). Eurocommunism. In S. Pons, \& R. Service (Eds.), A Dictionary of 20th Century Communism (pp. 310-313). Princeton: Princeton University Press.

Sartori, G. (1976). Parties and Party Systems: A Framework for Analysis. New York, NY: Cambridge University Press.

Spitaels, G. (1974). Le movement syndical en Belgique. Brussels: Editions de l'Université de Bruxelles.

Van Geyt, L. (1987). Pistes pour un non alignement européen (p. 148). Cahiers marxistes.

Van Geyt, L. (2015). La passion du trait d'union. Regards croisés sur le parti communiste de Belgique (1945-1985). Arquennes: Les Editions de la Mémoire.

Van Haute, E., \& Gauja, A. (2015). Party Members and Activists. London: Routledge.

Voerman, G. (2010). “Communisten, pacifistisch-socialisten, radicalenenprogressievechristenen. De voorlopers van Groen Links" and "Eenfusie in driebedrijven. De moeizametotstandkoming van Groen Links (1986-1990)". In G. Voerman, \& P. Lucardie (Eds.), Van de straatnaar de staat? GroenLinks, 1990-2010 (pp. 15-61). Amsterdam: Boom.

Voerman, G., \& Lucardie, P. (2016). GroenLinks in the Netherlands: No Longer a Protest Party, Not Yet a Coalition Partner. In E. van Haute (Ed.), Green Parties in Europe (140-157). London: Routledge. 